\title{
Occurrence of Mansonella ozzardi diagnosed using a polycarbonate membrane in a riverside population of Lábrea in the Western Brazilian Amazon
}

\author{
Sergio de Almeida Basano ${ }^{[1],[2],}$ Jansen Fernandes Medeiros ${ }^{[3]}$, Gilberto Fontes $^{[4]}$, \\ Gabriel de Deus Vieira ${ }^{[2]}$, Juliana Souza de Almeida Aranha Camargo[5], \\ Luana Janaína Souza Vera ${ }^{[2]}$, Ricardo de Godoi Mattos Ferreira ${ }^{[3]}$ \\ and Luís Marcelo Aranha Camargo[2],[5]
}

[1]. Centro de Medicina Tropical de Rondônia, Porto Velho, Rondônia, Brasil. [2]. Departamento de Medicina, Faculdade São Lucas, Porto Velho, Rondônia, Brasil. [3]. Fundação Oswaldo Cruz, Porto Velho, Rondônia, Brasil. [4]. Universidade Federal de São João del-Rei, Divinópolis, Minas Gerais, Brasil. [5]. Departamento de Parasitologia, Instituto de Ciências Biomédicas 5, Universidade de São Paulo, Monte Negro, Rondônia, Brasil.

\begin{abstract}
Introduction: Mansonella ozzardi is a widely distributed filaria worm in the Amazon region. This study aimed to determine the prevalence of $M$. ozzardi infection in riverine communities of Lábrea municipality, Amazonas State, Brazil. Methods: A diagnostic blood filtration method in a polycarbonate membrane was used. Results: M. ozzardi was found in $50.3 \%$ of the sample, with the highest prevalence in farmers/fishermen $\left(69.4 \% ; \chi^{2}=-19.14, \mathrm{p}<0.001\right)$. The prevalence was higher in longerterm residents ( $\geq 11$ years; $60.2 \%$ ). Conclusions: $M$. ozzardi infection rates are high near the Purus River, much greater than those previously reported based on diagnosis using thick blood smears.
\end{abstract}

Keywords: Mansonelliasis. Mansonella ozzardi. Brazilian Amazon.

Mansonella ozzardi is a widely distributed filaria worm that parasitizes humans in Amazonas State, Brazil, with high prevalences detected in residents of some regions of the Solimões, Negro, and Purus Rivers ${ }^{(1)(2)(3)(4)(5)}$. Simuliidae (blackflies) are the only vector of M. ozzardi in $\mathrm{Brazil}^{(6)(7)}$.

An endemic region for M. ozzardi in Brazil is in the municipality of Lábrea, in the Purus River region, Amazonas, where it has been detected since the first survey in the $1950 \mathrm{~s}^{(1)}$. Subsequent studies conducted in the 1970s and 1980s confirmed the wide distribution of $M$. ozzardi in this region ${ }^{(8)(9)}$. More recently, the prevalence of the infection had reportedly increased in riverine communities located near the Purus and Ituxi Rivers ${ }^{(2)(3)(4)}$.

In the Purus River region, only Adami et al. ${ }^{(10)}$ utilized the concentration method by Knott to diagnose mansonelliasis. Therefore, the present study aimed to determine the prevalence of $M$. ozzardi infection in riverine communities of the Lábrea municipality using a diagnostic blood filtration method in a polycarbonate membrane, which is more sensitive than thick blood smears ${ }^{(11)}$.

This study was conducted in the riverside communities of the Purus River (Cassianã, Bacural, Jucuri, Buraco, Santa Rosa,

Corresponding author: Dr. Luís Marcelo Aranha Camargo.

e-mail: spider@icbusp.org

Received 4 May 2015

Accepted 7 July 2015
Jurucuá and Samaúma), located approximately $200 \mathrm{~km}$ from the municipality of Lábrea communities (S: $07^{\circ} 15^{\prime} 34^{\prime \prime}$ and W: 644ㄱ'59"), State of Amazonas, Brazil (Figure 1). The sample consisted of volunteer men, women, and children aged 5-60 years selected using convenience sampling. Data and blood samples were collected after signing the free and informed consent form by the individual or the legal guardian. Of the estimated 350 inhabitants in the included communities, $171(48.6 \%)$ inhabitants were present at the time of the study and agreed to participate.

To estimate the prevalence of Mansonella ozzardi, blood was filtrated in a polycarbonate membrane ${ }^{(12)}$. First, $1 \mathrm{~mL}$ venous blood was collected from each individual, diluted in $10 \mathrm{~mL} 0.9 \%$ saline, and filtered in a polycarbonate membrane (Nucleopore Corporation, Pleasanton, CA, USA) with a $3 \mu \mathrm{m}$ pore diameter. Then, the membranes were removed from the filters and mounted on microscope slides, fixed in methanol, stained with a Panoptic kit ${ }^{\circledR}$, and examined under an optical microscope with a 200 magnification to search for M. ozzardi microfilariae.

The prevalence of microfilaremia was compared between sexes and length of residence (1-5, 6-10, and $\geq 11$ years) using Chi-squared tests and between age groups $(5-15,16-30,31-$ 45 , and 46-60 years) and occupations (farmer/fisherman, housewife, student, and others) using linear generalized models, followed by a contrast analysis to verify the specific groups between which differences existed. In addition, trend analysis was conducted for length of residence ${ }^{(13)}$. Furthermore, 


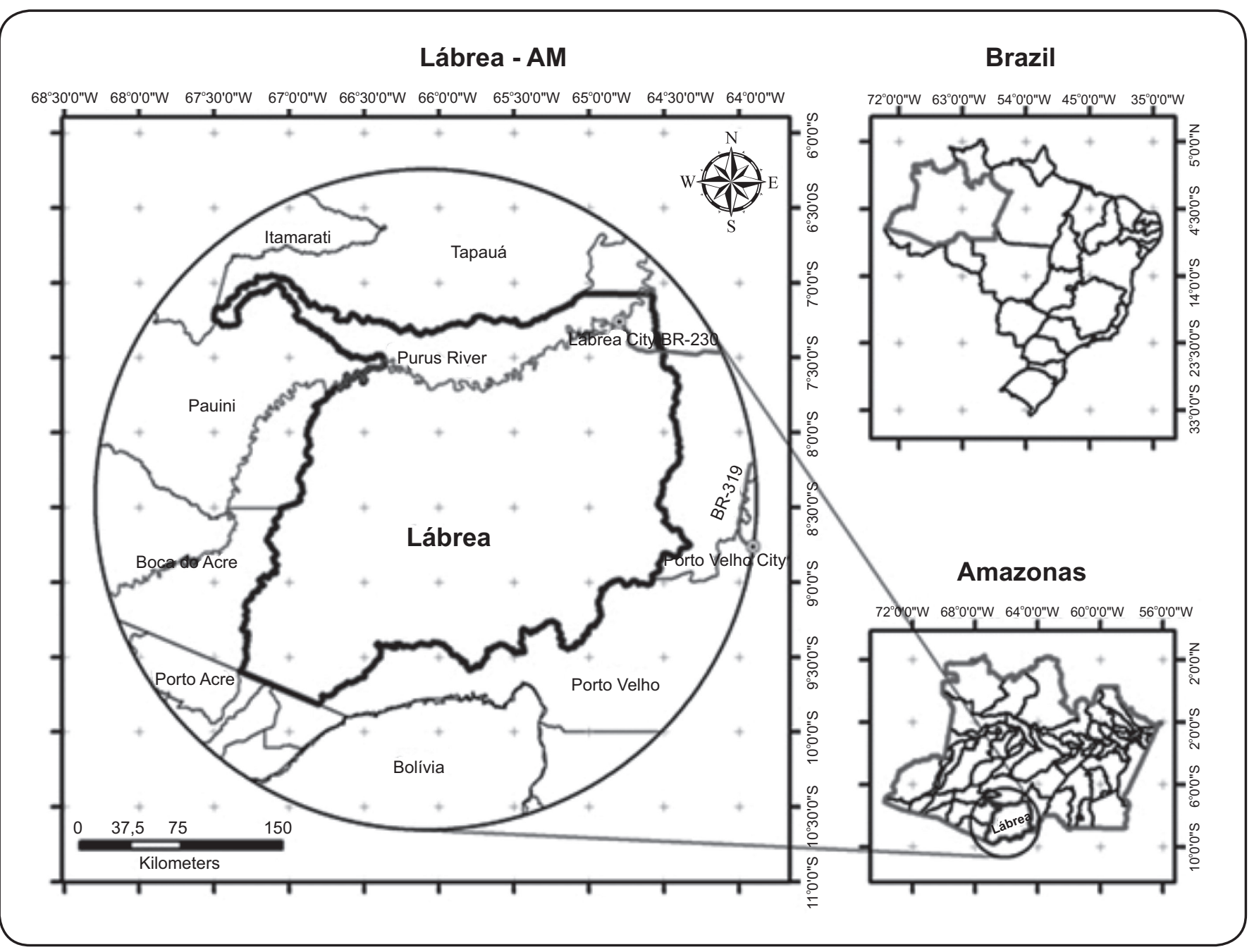

FIGURE 1 - Municipalities of the Lábrea region in State of Amazonas, Brazil.

odds ratios (ORs) and 95\% confidence intervals (CIs) were determined for each group using OpenEpi. The data were adjusted to a binomial distribution for errors and analyzed with a significance level of $5 \%$.

Of the 171 individuals examined, 50.3\% (95\% CI: $42.8-$ 57.8 ) had microfilariae, and the proportion of microfilaremic individuals in the different communities was 38.9-66.7\% (Table 1). The prevalence was higher in men (52.5\%) than in women $(48.4 \%)$, but this was not significant $(\mathrm{p}=0.644)$. The number of microfilaremic individuals significantly increased with age (ANOVA $\chi^{2}=-15.82, \mathrm{p}<0.001$ ) (Table 1). The prevalence of $M$. ozzardi was higher in male farmers/fishermen $(34 / 49 ; 69.4 \%)$ and in housewives $(30 / 50 ; 60.0 \%)$ than in the other occupational groups (ANOVA $\chi^{2}=-19.14, p<0.001$ ).

Men had a higher odds of infection than women (OR: $1.18 ; 95 \%$ CI: 0.64-2.16). The highest odds of infection by occupation was in farmers/fishermen (OR: 5.32; $95 \%$ CI: 2.38-11.8) and by age was in those aged $45-60$ years (OR: 5.06; 95\% CI: 1.84-14.5) (Table 1). Length of residence was available for 166 individuals, and the prevalence increased with the length of residence $\left(\mathrm{A}=11.33 ; \chi^{2}=4,66, \mathrm{p}=0.03\right): 1-5$ years, $24 \%$ (6/25); $5-10$ years, $39.5 \%$ (15/38); and $\geq 11$ years, $60.2 \%(62 / 103)$.

To the best of our knowledge, this is the first epidemiological survey to use blood filtration in a polycarbonate membrane to diagnose M. ozzardi in the Purus River region. Our data support the high prevalences $(>50 \%)$ of mansonelliasis in the riverine population of Purus reported in previous studies ${ }^{(10)(14)}$. However, the rate $(50.3 \%)$ of $M$. ozzardi infections in the present study was higher than that $(20.7 \%)$ in another study conducted in the Purus River region in Lábrea that used thick blood smears ${ }^{(4)}$. In other Purus River municipalities, such as Pauini and Boca do Acre, prevalences of $24.8 \%$ and $24.1 \%$, respectively, were previously reported ${ }^{(3)}{ }^{(14)}$. Therefore, lower prevalences were detected using the thick blood smear method, indicating lower sensitivity of this method and consequently under-reporting of the prevalence of $M$. ozzardi microfilaremic individuals in the Purus River region. Using the method by Knott, high parasitic loads were reported in the communities of the Purus River: 63.3\% in Monte Verde and 54.5\% in Praia do Gado, both in 
TABLE 1 - Prevalence of Mansonella ozzardi microfilaremia, diagnosed using blood filtration in a polycarbonate membrane, according to riverine community, sex, age group, and occupation in the Purus River, Lábrea municipality, Amazonas State, Brazil, 2009.

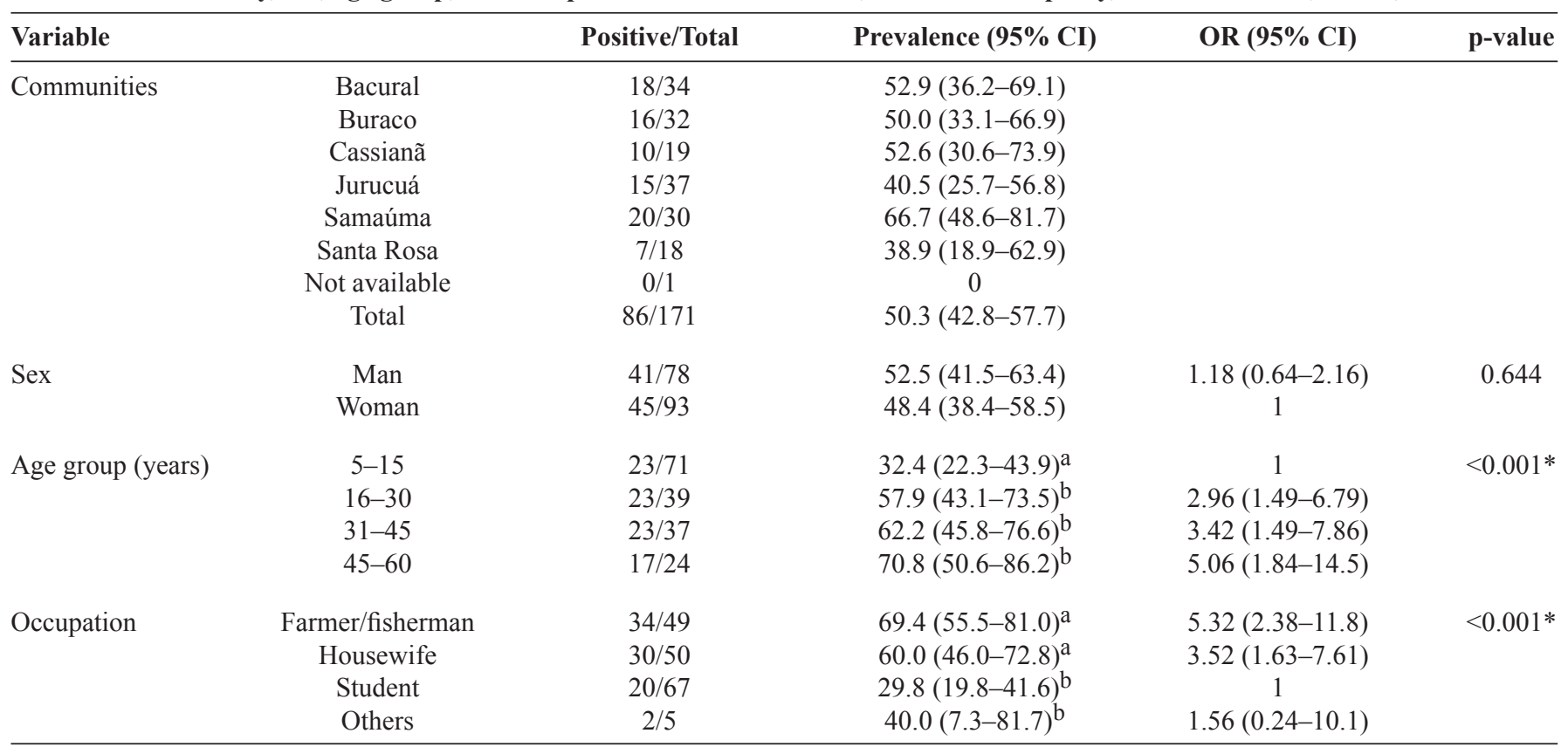

*Different letters $\mathbf{a} \mathbf{b}$ indicate statistical differences $(\mathrm{p}<0.05)$. CI: confidence interval; OR: odds ratio.

the Boca do Acre municipality ${ }^{(10)}$. In addition, the infection rates observed in Monte Verde in the present study were much higher than previously described $(33.3 \%)^{(14)}$. Polymerase chain reaction $(72.3 \%$ positive) is also reportedly more sensitive than thick blood smear ( $42.6 \%$ positive) for the diagnosis of M. ozzardi ${ }^{(10)(15)}$.

The slightly higher prevalence in men, although not significant, is possibly attributed to the increased contact of men with insect vectors in their day-to-day activities and is consistent with the observation of other studies conducted in Amazonas State ${ }^{(3)}(4)$ (5) (9). This degree of exposure to Simuliidae bites also explains the higher prevalence in individuals that work in fields, such as farmers, and in those of older age ${ }^{(3)(4)(5)(10)}$. In this particular scenario, women are highly exposed to vectors due to working in the fields with their husbands, leading to a high infection rate.

Longer residence duration in the communities ( $\geq 11$ years of residence) was also associated with higher rates of infection, indicating that the length of residence in an endemic area and consequent exposure to vectors are crucial for the maintenance of $M$. ozzardi infection. This is possibly one of the factors responsible for accumulation of parasites in individuals, maintaining several adult worms of different ages with continuous production of microfilariae, infection, and transmission by insect vectors ${ }^{(3)(5)}$. There are no previous reports of residence duration and prevalence rates of mansonelliasis; however, this relationship possibly also occurs in other regions.

Another important finding was that blood filtration using a polycarbonate membrane was able to detect a high number of parasitized children and adolescents aged 5-15 years (32.4\%); this rate was higher than studies that used the thick blood smear method, with prevalences of $20.7 \%, 9.7 \%$, and $10.2 \%$, respectively, in children aged 10-18 years ${ }^{(2)(3)(4)}$.

The present study showed that $M$. ozzardi infection was present in $50.3 \%$ of the local sample, suggesting that the prevalence of this parasite in the region is higher than those recorded in recent surveys ${ }^{(2)(3)(4)}$. Furthermore, blood filtration using a polycarbonate membrane can be used in epidemiological surveys, especially in regions of low microfilariae density or in post-treatment control programs, during which this method can be performed in the field with minimum requirements to store blood for later analysis. Finally, an appropriate control model should be structured of this Amazonian endemic disease, which is currently neglected by the health authorities.

\section{Ethical approval}

The study was approved by the Ethics Committee of the Faculdade São Lucas, Porto Velho City, State of Rondonia (344/09 registry). All patients signed the free and informed consent term.

\section{CONFLICT OF INTEREST}

The authors declare that there is no conflict of interest.

\section{REFERENCES}

1. Lacerda NB, Rachou RG. Filarioses humanas nas sedes municipais do estado do Amazonas e territórios do Acre, Guaporé e Rio Branco. Rev Bras Malariol Doenças Trop 1956; 8: 437-442. 
2. Medeiros JF, Py-Daniel V, Barbosa UC, Ogawa GM. Current profile of Mansonella ozzardi (Nematoda: Onchocercidae) in communities along the Ituxi river, Lábrea municipality, Amazonas, Brazil. Mem Inst Oswaldo Cruz 2008;103: 409-411.

3. Medeiros JF, Py-Daniel V, Barbosa UC, Izzo TJ. Mansonella ozzardi in Brazil: prevalence of infection in riverine communities in the Purus region, in the state of Amazonas. Mem Inst Oswaldo Cruz 2009a;104:74-80.

4. Medeiros JF, Py-Daniel V, Barbosa UC. Prevalence of Mansonella ozzardi among riverine communities in the municipality of Lábrea, state of Amazonas, Brazil. Rev Soc Bras Med Trop 2011; 44:186-190.

5. Martins M, Pessoa FAC, Medeiros MB, Andrade EV, Medeiros JF. Mansonella ozzardi in Amazonas, Brazil: prevalence and distribution in the municipality of Coari, in the middle Solimões river. Mem Inst Oswaldo Cruz 2010;105: 246-253.

6. Batista D, Cerqueira NL, Moraes MAP. Epidemiologia da mansonelose em localidade do interior do Amazonas. Rev Ass Med Bras 1960a; 6:176-184.

7. Cerqueira NL. Sobre a transmissão da Mansonella ozzardi. J Bras Med 1959; 1: 885-914.

8. Shelley AJA. Preliminary survey of the prevalence of Mansonella ozzardi in some rural communities on the river Purus, state of Amazonas, Brasil. Ann Trop Med Parasitol 1975; 69: 407-412.
9. Tavares AM. Estudo da infecção por Mansonella ozzardi. [Master's Thesis]. [Brasília]: Universidade de Brasília; 1981. 122 p.

10. Adami YL, Rodrigues G, Alves MC, Moraes MAP, Banic MD, Maia-Herzog M. New records of Mansonella ozzardi: a parasite that is spreading from the state of Amazonas to previously uninfected areas of the state of Acre in the Purus River region. Mem Inst Oswaldo Cruz 2014; 109: 87-92.

11. Fontes G, Rocha EMM. Wuchereria bancrofti - Filariose linfática. In: Neves DP, Melo AL, Linardi PM, Vitor RWA, editors. Parasitologia Humana. 12 ${ }^{\text {ed }}$. Rio de Janeiro: Ed. Atheneu; 2011. p. 323-333.

12. Dennis DT, Kean BH. Isolation of microfilariae: report of a new method. J Parasit 1971; 57: 1146-1157.

13. Ayres M, Ayres Jr M, Ayres DL, Santos AA. Bioestat 5.0. São Paulo: USP; 2007. 359p.

14. Medeiros JF, Py-Daniel V, Barbosa UC, Ogawa GM. Ocorrência da Mansonella ozzardi (Nematoda, Onchocercidae) em comunidades ribeirinhas do rio Purus, Município de Boca do Acre, Amazonas, Brasil. Cad Saude Publica 2009b; 25:1421-1426.

15. Vera LJ, Basano SA, Camargo JS, França AK, Casseb AA, Medeiros JF, et al. Improvement of a PCR test to diagnose infection by Mansonella ozzardi. Rev Soc Bras Med Trop 2011; 44:380-382. 